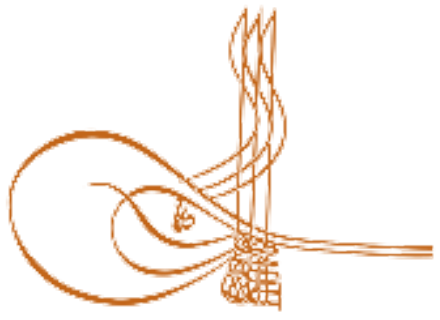

www.turkishstudies.net/education
Turkish Studies - Educational Sciences

eISSN: $2667-5609$

Research Article / Araștırma Makalesi

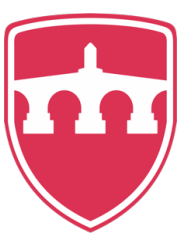

INTERNATIONAL

BALKAN

UNIVERSITY

Sponsored by IBU

\title{
Fen Bilimleri Dersinde Dereceli Puanlama Anahtarı Kullanımı ve Puanlama Anahtarına İlişkin Öğrenci Görüşleri: Bir Karma Yöntem Çalışması ${ }^{1}$
}

\author{
The Use of Scoring Rubric in Science Course and Student Opinions on the Scoring Rubric: A \\ Mixed Method Study
}

Sümeyye Aydın Gürler ${ }^{*}$ Oktay Baykara**

\begin{abstract}
In addition to the (traditional) measurement and assessment approaches that indicate the ratio with which students have acquired the targeted behaviors of the course, there is also a need for (alternative) approaches which put forth the ratio with which students put to use the behaviors they acquire. It is important to use the proper measurement and assessment tool for each course. Undoubtedly, Science is one of these courses. The purpose of the present study was to use the Scoring Rubric (SR) which is one of the alternative measurement and assessment tools for the evaluation of the acquisition of secondary school students regarding a unit in Science course. Mixed method utilizing both qualitative and quantitative techniques has been used in the study. A semi-experimental model was used for collecting quantitative data, whereas case study pattern was used for the collection of qualitative data. The study group was comprised of a total of 25 students continuing $6^{\text {th }}$ grade at a state secondary school at the Gaziantep-Karkamış district center during the 2013-2014 academic year. Quantitative data were acquired using the Academic Success Test on the Particulate Structure and Characteristics of Matter. Whereas a semi-structured interview form was used for the acquisition of qualitative data. Two sample t-tests with one dependent and one independent were used for the quantitative dimension, while content analysis method was used for the qualitative data. Based on the quantitative data acquired as a result of the study, it was observed that the use SR when solving questions increases the success of students significantly and that gender does not play a role on student scores. Qualitative results put forth that SR reduces the time lost during assessment, that it guides both the teacher and the student, makes a positive impact on student learning and puts forth cases of inadequate learning.
\end{abstract}

\footnotetext{
${ }^{1} \mathrm{Bu}$ çalışma, ilk yazarın "Kazanımlara Yönelik Dereceli Puanlama Anahtarlarının Geliştirilmesi, Kullanılması ve Değerlendirmede Objektifliğe Katkısı" başlıklı doktora tezinden üretilmiştir.

* Dr. Öğr. Üyesi, Gaziantep Üniversitesi, Nizip Eğitim Fakültesi, Matematik ve Fen Bilimleri Eğitimi Bölümü Asst. Prof., Gaziantep University, Nizip Faculty of Education, Department of Mathematics and Science Education ORCID 0000-0003-2651-4395

s.aydingurler@gmail.com

** Prof. Dr., Fırat Üniversitesi, Eğitim Fakültesi, Matematik ve Fen Bilimleri Eğitimi Bölümü

Prof., Firat University, Faculty of Education, Department of Mathematics and Science Education ORCID 0000-0003-4429-0401

obaykara@firat.edu.tr
}

Cite as/ Atıf: Aydın Gürler, S. \& Baykra, O. (2020). Fen bilimleri dersinde dereceli puanlama anahtarı kullanımı ve puanlama anahtarına ilişkin öğrenci görüşleri: Bir karma yöntem çalışması, Turkish Studies - Education, 15(2), 673690. https://dx.doi.org/10.29228/TurkishStudies.41697

Received/Geliş: 09 February/Şubat 2020

Accepted/Kabul: 25 April/Nisan 2020

Checked by plagiarism software

Copyright (C) INTAC LTD, Turkey 
Structured Abstract: Introduction The use of traditional assessment and evaluation methods for measuring student performance in Science course does not provide sufficiently reliable and valid results. Because the objective of the Science and Technology Course put into effect in 2004 has been determined as making all students science literate individuals regardless of individual differences (MEB, 2005). Hence, there has been a need for alternative assessment approaches to raise science literate individuals. Because alternative assessment and evaluation enables us to identify different aspects of the student. The primary purpose of the present study was to use the scoring rubric (SR) which is one of the modern assessment tools for assessing the level of learning of secondary school sixth grade students related with a selected unit (Particulate Structure and Characteristics of Matter). For this purpose, answers were sought for the following questions:

1. Is there a statistically significant difference between the level of success of students in answering the questions in the Particulate Structure and Characteristics of Matter (PSCM) unit after SR use in comparison with their level of success prior to the use of SR?

2. Is there a statistically significant relationship between the use of SR by students and their level of success in soling PSCM unit related problems and gender?

3. What are the opinions of students who implement SR during the instruction process with regard to this assessment and evaluation method and with regard to SR?

\section{Literature Review}

It was observed when national and international literature on SR was examined that there are studies on the use of SR in the assessment of the presentation skills and material assessment, on the development of SR related attitude scales and on the acquisition of student opinions (Erman Aslanoğlu and Kutlu, 2003; Kurt and İzmirli, 2010; Kutlu, Yıldırım and Bilican, 2009; Güneş and Soran, 2013). However, very few studies were determined as a result of the literature survey carried out on the use of SR for assessing the level at which students have understood a certain topic. It is considered that the study will provide a different example for field educators interested in this topic since the subject is current and is based on the constructivist learning approach which is one of the modern learning approaches. Moreover, it is also thought that the present study will also guide not only Science teachers but teachers of all other disciplines who wish to utilize such a rubric in their courses.

\section{Method}

"Sequential Explanatory Mixed Method Pattern" from among the mixed method patterns was used in this study. This approach is comprised of two stages: in the first stage quantitative data were acquired and analyzed. Whereas in the second stage, the acquired findings were explained in-depth and restructured via qualitative research. A semi-experimental model was used for the acquisition of quantitative data. Single group pre-test-post-test, experimental pattern without control group was used in the semi-experimental model. The qualitative dimension of the study was carried out using the case study pattern which is among the qualitative research methods. Two different methods were used for data acquisition in the study. The Particulate Structure and Characteristics of Matter Unit Academic Success Test developed by the researcher was used as quantitative data acquisition tool. While interview method was used as the qualitative data acquisition method. The study group was comprised of 25 students continuing their education at the secondary school $6^{\text {th }}$ grade of a state run secondary school in the Karkamış district of Gaziantep province during the 2013-2014 academic year.

\section{Findings and Discussion}

It was observed when the results put forth by the quantitative data acquired during the study were examined that the use of SR by students when solving problems related with the PSCM unit increased their success levels significantly. This finding is similar with the results of various other studies (Aytaç, 2006; Tuncel, 2011; Neukom, 2000; Martinez, 1997) in which SR has been utilized as the assessment method. Aytaç (2006) carried out a study in which it was put forth that the use of SR as an assessment method increases the success of the students and provides more reliable findings with regard to assessment results. Tuncel (2010) carried out a study as a result of which it was reported that the use of rubric (SR) in social sciences course is an effective assessment tool. Neukom (2000) also utilized rubric (SR) for the assessment of homework and observed its positive impacts on learning. Martinez (1997) carried out a study in which students were more successful in writing homework in a class using rubric (SR) for assessment meaning that they are aware of the assessment criteria. It can be observed when the results obtained by way of qualitative findings were examined that these results are in accordance with the findings in many other studies in the relevant literature. Based on 
the results obtained by way of qualitative findings, it was determined that it is important to use SR when assessing learning and that it is important to know the assessment criteria beforehand (Erman Aslanoğlu and Kutlu, 2003), that SR acts as a guide for both the teachers and the students, that thanks to SR students have knowledge of assessment criteria, that the time lost during assessment is reduced (Mullen, 2003), that it plays an important role in the assessment of student learning (Saxe et al., 1999), that it makes student learning easier and makes positive contributions to student learning (Vaughn, 2002).

\section{Conclusion and Suggestions}

Alternative (complementary) measurement and assessment methods not only measure the knowledge level of the students but also support their multidimensional development (creativity, self-criticism skills etc.). It has been observed in the present study that the use of SR by students when solving problems on the PSCM unit increased their success levels significantly. Moreover, it was concluded that gender does not have any impact on the scores of the students. Fairer and more consistent assessment results have been obtained when the responses of the students to problems related with the PSCM unit are assessed in accordance with SR. Based on the findings of this study, the following suggestions can be made: self and peer assessment can also be carried out in addition to teacher assessment while assessing the exam papers via SR. The use of SR developed by himself/herself or together with his/her students while assessing a unit or project may be more effective. Families should be informed on SR. Because SR can provide abstract proofs especially when teachers are trying to explain to the families the criteria with which they have assessed the performance of the students especially in their projects. In addition, informative seminars on alternative assessment and evaluation methods can be organized by the Ministry of Education for informing teachers, students and custodians on this issue.

Keywords: Science Education, Alternative Assessment, Science Course, Scoring Rubric, Secondary School Student.

Öz: Öğrencilerin dersin hedef davranışlarını ne oranda kazandıklarını gösteren ölçme ve değerlendirme yaklaşımlarının (geleneksel) yanı sıra, öğrencilerin kazandıkları davranışları hangi oranda kullandıklarını gösteren yaklaşımlara (alternatif) da ihtiyaç vardır. Her derse uygun ölçme ve değerlendirme aracının kullanılması önemlidir. Bu derslerden biri de şüphesiz ki Fen Bilimleri dersidir. Bu çalışmanın amacı ortaokul öğrencilerinin Fen Bilimleri dersinde bir üniteye ait konuları öğrenmelerinin değerlendirilmesinde alternatif ölçme değerlendirme araçlarından biri olan Dereceli Puanlama Anahtarının (DPA) kullanılmasıdır. Araştırmada, nicel ve nitel tekniklerin bir arada kullanıldığı karma yöntem kullanılmıştır. Nicel verilerin toplanmasında yarı-deneysel bir model, nitel verilerin toplanılmasında ise durum çalışması deseni kullanılmıştır. Araştırmanın çalışma grubunu, 2013-2014 eğitim-öğretim yılında Gaziantep-Karkamış ilçe merkezine bağlı devlet ortaokulunun 6. sınıfına devam eden 25 öğrenci oluşturmaktadır. Nicel veriler araştırmacı tarafından geliştirilen Maddenin Tanecikli Yapısı ve Özellikleri Ünitesi Akademik Başarı Testi ile elde edilmiştir. Nitel verilerin toplanılmasında ise yarı yapılandırılmış görüşme formu kullanılmıştır. Nicel boyutta elde edilen verilerde bağımlı ve bağımsız iki örnek t-testi, nitel boyutta elde edilen verilerde ise içerik analizi yöntemi kullanılmıştır. Araştırmadan elde edilen nicel sonuçlara göre, öğrencilerin soru çözümünde DPA kullanmalarının başarılarını önemli oranda artırdığı ve cinsiyet türünün öğrencilerin aldıkları puanlarda bir etken olmadığ1 görülmüştür. Nitel sonuçlara göre ise DPA'nın değerlendirmede zaman kaybını azalttığı, öğretmen ve öğrenciye rehberlik ettiği, öğrenci öğrenmesine olumlu yönde katkıda bulunduğu, öğrenme eksikliklerini ortaya çıkardığı görülmüştür.

Anahtar Kelimeler: Fen Eğitimi, Alternatif Değerlendirme, Dereceli Puanlama Anahtarı, Fen Bilimleri Dersi, Ortaokul Öğrencisi.

\section{Giriş}

Son yüzyılda dünyamızda bilimsel bilgi ve teknoloji alanında yaşanan değişimlerden eğitim kurumları da etkilenmiş olup, eğitim bilimleri alanlarında da çeşitli değişmeler görülmüştür. Önemli değişikliklerin görüldüğü eğitim alanlarından biri de ölçme ve değerlendirmedir (Kutlu, Yıldırım ve Bilican, 2009: 77). Uzun yıllar ölçme-değerlendirme yapılırken öğrenme çıktılarına (sonuca) ve öğrencilerin birbirlerine kıyasla öğrenmelerinin nasıl olduğuna odaklanılmıştır. Geleneksel ölçme 
araçları (çoktan seçmeli, klasik sınavlar vb.) öğrencinin bilgisini kısa bir zaman dilimi içinde ölçmeye çalıştığından öğrenciye başarısı ve eksiklikleri hakkında yeterince dönüt verememekle birlikte, öğretmen de öğrenmenin nasıl gerçekleştiği konusunda yeterli bilgi sunamamaktadır (Shepard, 1989). Kısacası geleneksel ölçme değerlendirme yaklaşımları öğrencilerin farklı düşüncelerini değerlendirmede yeterli değildir (Krajcik, Czerniak ve Berger, 1999). Teknoloji ve bilgi çağ 1 olarak adlandırılan günümüzde bilgi çok çabuk değişmektedir. Dolayısıyla bu çağda öğrenciden beklenen sadece sahip olduğu bilgiyi aklında tutması değil, eski bilgilerini yeni bilgilerin üzerine inşa ederek bu bilgilerini yeni ve farklı durumlarda kullanabilmesidir. Öğrenci başarısını sadece verilen notla değerlendirip ve bu nota göre "geçti" veya "kaldı" gibi yargılara varan günümüzdeki geleneksel ölçme değerlendirme anlayışının dışına çıkılması gerekir. Yani öğrencilerin dersin hedef davranışlarını ne oranda kazandıklarını gösteren ölçme ve değerlendirme yaklaşımlarının yanı sıra, öğrencilerin kazandıkları davranışları hangi oranda kullandıklarını gösterecek yaklaşımlara da ihtiyaç vardır. Kısacası bu yeni yaklaşımlara göre sadece sonuç değil öğrenme süreci de değerlendirmeye katılmalıdır. Bu durum ise alternatif durum belirleme yaklaşımlarının kullanılmasını gerekli kılmıştır (Shepard, 2000: 4). Alternatif durum belirleme yaklaşımları içinde ise performansa dayalı durum belirleme yaklaşımı önemli bir yere sahiptir. Performansa dayalı durum belirlemenin performans görevi ve dereceli puanlama anahtar olmak üzere iki ana bölümü vardır (Popham, 2000). Marzano, Pickering ve Mctighe (1993) göre etkili öğrenmenin temeli olan bilgiyi yapılandırma yöntemlerinden biri de öğrencilere performans görevleri vermektir. Performansa dayalı durum belirlemenin önemli bir bölümünü oluşturan dereceli puanlama anahtarları (DPA) ise tanımlanmış kategorilerden uygun düşen boyuta gözlemlerimize ait puanları kaydetmemizi sağlayan bir değerlendirme aracıdır (Haladyna, 1997). DPA; değerlendirme ölçütleri, ölçüt tanımlamaları ve bir puanlama stratejisi olmak üzere üç bölümden oluşur. Değerlendirme ölçütleri; kabul edilebilir yanıtları kabul edilemez yanıtlardan ayırır. Ölçüt tanımlamaları; öğrencilerin yanıtlarındaki farklılıkları tanımlama yolunu gösterir. Puanlama stratejisi ise değerlendirmenin amacına bağlı olarak bütünsel (holistic) veya analitik (analitical) biçimde olabilir (Popham, 1997: 12). Brookhart (1999) göre yapılan bir değerlendirmede performansın farklı düzeylerini ortaya çıkarmak için performansı bağımsız ölçütlere ayırmak mümkün olmadığında bütünsel puanlama anahtarı kullanılmalıdır. Kısacası bu DPA türü daha çok öğrenme ürünleri toplam puan olarak değerlendirilmek istenildiğinde kullanılır (Birel ve Albuz, 2014: 86). Ölçülen bir yetenek boyutu öğelere ayrılarak daha ayrıntılı bir puanlama yapılmak istenildiğinde ise analitik puanlama anahtarı kullanılır (Haladyna, 1997). Analitik (çözümleyici) DPA'lar öğrencilerden detaylı bilgiler edinmek adına ideal bir DPA'dır (Schirmer ve Bailey, 2000: 52).

Her derse uygun ölçme ve değerlendirme araçlarının kullanılması önemlidir. Bu derslerden biri de şüphesiz ki Fen Bilimleri dersidir. Fen Bilimleri dersinde öğrenci performansını ölçmede geleneksel ölçme değerlendirme yöntemlerinin kullanılması öğrencilerin performanslarını ölçmede yeterince güvenilir ve geçerli bir sonuç sağlamaz. Çünkü 2004 yılında uygulamaya konulan Fen ve Teknoloji Dersi'nin amacı bireysel farklılıklar dikkate alınmaksızın tüm öğrencilerin fen okuryazar birey olması olarak belirlenmiştir (MEB, 2005). Fen okuryazar birey; araştıran, sorgulayan, eleştirel düşünebilen, kendine güvenen, fen bilimlerine karşı olumlu tutuma sahip olan birey demektir (MEB, 2013). Fen okuryazar birey yetiştirebilmek için de farklı alternatif değerlendirme yaklaşımlarına ihtiyaç duyulmuştur. Çünkü alternatif ölçme değerlendirme öğrenciyi farklı yönleriyle tanıma firsatı verir (Çoruhlu, Nas ve Çepni, 2009). Bu çalışmanın temel amacı; ortaokul altıncı sınıf öğrencilerinin seçilen bir üniteye (Maddenin Tanecikli Yapısı ve Özellikleri) ait konuları öğrenmelerinin değerlendirilmesinde çağdaş ölçme değerlendirme araçlarından biri olan DPA'nın kullanılmasıdır. $\mathrm{Bu}$ amaç doğrultusunda şu sorulara cevap aranmıştır.

1. Öğrencilerin DPA kullanımı sonrasındaki Maddenin Tanecikli Yapısı ve Özellikleri (MTYÖ) ünitesindeki soruları çözme başarıları DPA kullanımı öncesindeki başarılarına göre anlamlı bir farkl1lık göstermekte midir? 
2. Öğrencilerin DPA kullanımı ile MTYÖ ünitesiyle ilgili problemleri çözmedeki başarıları ile cinsiyet arasında anlamlı bir ilişki var mıdır?

3. Öğretim sürecinde DPA'y1 kullanan öğrencilerin bu şekildeki ölçme değerlendirme yöntemine ve DPA'ya ilişsin görüşleri nelerdir?

\section{Yöntem}

\section{Araștırmanın Modeli}

$\mathrm{Bu}$ çalışmada nicel ve nitel araştırma yöntemlerinin bir arada kullanıldığı karma yöntem kullanılmıştır. Karma yöntemin kullanıldığı araştırmalarda amaçlı olarak iki ya da daha fazla veri toplama yolu veya en az iki farklı araştırma modelinden yararlanılmaktadır (Creswell, 2009; Green, Krayder ve Mayer, 2005). Creswell ve Plano-Clark (2007) göre birbirini destekleyen nicel ve nitel yöntemlerin bir arada kullanılması araştırma problemiyle ilgili daha kapsamlı yorumlamaların yapılmasına imkân verir. Yapılan bu araştırmada karma yöntem desenlerinden "Açımlayıcı Sıralı Karma Yöntem Deseni” kullanılmıştır. Bu desenin amacı; nicel bulguları daha detaylı bir şekilde açıklamak için nitel verileri kullanmaktır. Bu yaklaşım iki aşamadan oluşmaktadır: Birinci aşamada nicel veriler toplanır ve analiz edilir. İkinci aşamada ise elde edilen bulgular nitel araştırmayla daha detaylı bir şekilde açıklanarak tekrar yapılandırılır. Bu desende nicel veri sonuçları nitel verilerle açıklandığ için açımlayıcl; nicel aşamayı nitel bir aşama takip ettiği için de sıralı olarak isimlendirilir (Creswell, 2017).

\section{Nicel Boyut}

Öğrencilerin MTYÖ ünitesi ile ilgili soruları çözme başarılarının DPA kullanımına bağlı olup olmadığı ve öğrencilerin DPA kullanımına bağlı olarak MTYÖ ünitesiyle ilgili problemleri çözmedeki başarıları ile cinsiyet arasında ilişki olup olmadığını belirlemek için gerekli olan nicel verilerin toplanmasında yarı-deneysel bir model kullanılmıştır. Yarı-deneysel modelde, tek grup ön test-son test, kontrol grupsuz deney deseni kullanılmıştır. Bu desende deneysel işlemin etkisi tek bir grup üzerinde test edilir. Bu desende tek gruba $(\mathrm{G})$ ait ön test ve son test değerleri arasındaki farkın $\left(\mathrm{O}_{1}-\mathrm{O}_{2}\right)$ anlamlılığ 1 test edilir. Desenin simgesel görünümü Tablo 1'de verilmiştir (Büyüköztürk ve diğ., 2008).

Tablo 1: Çalışmada Kullandığımız Desenin Simgesel Görünümü

\begin{tabular}{cccc}
\hline Grup & Ön test & İslem & Son test \\
$\mathrm{G}$ & $\mathrm{O}_{1}$ & $\mathrm{X}$ & $\mathrm{O}_{2}$ \\
\hline
\end{tabular}

( $\mathrm{G}$, işlem yapılan grup; $\mathrm{O}_{1}$, deney grubundan alınan ön ölçüm; $\mathrm{X}$, deneysel işlem; $\mathrm{O}_{2}$, deney grubundan alınan son ölçüm)

\section{Nitel Boyut}

Araştırmanın nitel boyutu ise nitel araştırma yöntemlerinden olan durum çalışması deseniyle gerçekleşmiştir. Nitel durum çalışmasında en belirgin özellik bir ya da birkaç durumun belirlenerek derinlemesine araştırılmasıdır. Bir duruma ilişkin etkenler bütüncül bir yaklaşımla araştırılarak ilgili durumu nasıl etkiledikleri veya ilgili durumdan nasıl etkilendikleri üzerine odaklanılır (Silverman, 2006). Bu amaçla çalışmada DPA'nın oluşturulmasından önce uygulan ön test sorularının ve DPA'nın oluşturulmasindan sonra uygulanan son test sorularının DPA'ya göre değerlendirme sürecinin ögrenciler tarafindan nasıl değerlendirildiği durumu belirlenmiş ve belirlenen bu durumla ilgili öğrenci görüşleri alınarak derinlemesine bir analiz yapılmıştır.

\section{Katılımcilar}

Araştırmanın çalışma grubunu; 2013-2014 eğitim-öğretim yılında Gaziantep-Karkamış ilçe merkezine bağlı bir devlet ortaokulunun 6. sınıfına devam eden 25 öğrenci oluşturmaktadır. 
Araştırmanın çalışma grubunun belirlenmesinde araştırmacı için kolay ulaşılabilir olduğundan araştırmacının çalıştı̆̆ okul seçilmiştir. Bahsi geçen okulda bir tane 6 . sınıf şubesi bulunmaktadır. Araştırmaya hız kazandırılması bakımından, nicel çalışma grubunun belirlenmesinde uygun veya elverişlilik örnekleme yöntemi kullanılmıştır. Çünkü bu yöntemde yakın ve erişilmesi kolay olan bir durum seçilir. $\mathrm{Bu}$ örnekleme yöntemi daha çok araştırmacının diğer örnekleme yöntemlerini kullanma imkânının olmadığı durumlarda kullanılır (Kılıç, 2013). Bu çalışmada da araştırmacının görev yaptığı okulun köy okulu olması ve 6 . sınıf düzeyinde tek şubenin olmasından dolayı diğer örnekleme yöntemlerini kullanma imkânı olmadığından uygun veya elverişlilik yöntemi kullanılmıştır.

Karma yöntem araştırmalarında, araştırmanın nicel ve nitel bölümleri için genellikle farklı büyüklükteki gruplar ile çalışılır. Nitel verilerin toplandığı çalışma grubu genellikle nicel verilerin toplandığ çalışma grubunun içinden seçilen daha az sayıdaki bireyden oluşur (Creswell ve PlanoClark, 2007). Bu çalışmada da nitel çalışma grubu amaçlı örnekleme stratejisine bağlı olarak nicel çalışma grubunun içerisinden seçilen daha az kişiden oluşmuştur. Bu strateji için öncelikle hangi öğrencilerin çalışma grubunda yer alacağına ilişsin seçim kriterleri oluşturulması gerekir (Merriam, 2013). Bu amaçla, nitel çalışma grubunun belirlenmesinde seçim kriterleri olarak çalışma grubuna gönüllü ve istekli olarak katılma ve uygulamalar esnasında devamsızlık yapmama kriterleri belirlenmiştir. Nitel çalışma grubu bahsedilen kriterleri sağlayan 7 öğrenci ile oluşturulmuştur.

\section{Veri Toplama Araçları}

Araştırmada veriler iki farklı yöntemle elde edilmiştir. Nicel veri toplama aracı olarak araştırmacı tarafından geliştirilen Maddenin Tanecikli Yapısı ve Özellikleri Ünitesi Akademik Başarı Testi (MTYÖÜABT) kullanılmıştır. MTYÖÜABT; Maddeyi Oluşturan Tanecikler konusundan 6; Elementler ve Bileşikler konusundan 6; Fiziksel ve Kimyasal Değişim konusundan 8, Maddenin Hallerinin ve Tanecikli Yapısı konusundan 2 olmak üzere toplam 22 çoktan seçmeli test sorusundan oluşmaktadır. Bu sorular öğrencilere DPA'nın oluşturulmasından önce ön test olarak ve DPA'nın oluşturulmasından sonra son test olarak uygulanmıştır. Nitel verilerin toplanılmasında ise nitel veri toplama yöntemi olarak görüşme yöntemi kullanılmıştır. Bu amaçla da araştırmacılar tarafından yarı yapılandırılmış görüşme formu hazırlanılmıştır. Wengraf (2001) göre bu görüşme türü görüşme sırasında ihtiyaç duyulması halinde soruların yeniden düzenlenmesine firsat verdiğinden nitel çalışmalarda çok sık tercih edilmektedir. Araştırmacılar tarafından alan uzmanlarının da görüşleri alınarak taslak bir görüşme formu hazırlanmıştır. Taslak formda öğrencilerin fen bilimleri dersinde DPA kullanımına ilişkin görüşlerini belirlemeye yönelik dört soru yer almaktadır. Asıl uygulamaya geçilmeden önce soruların anlaşılabilirliğini test etmek amacıyla üç öğrenciyle ön uygulama yapılmıştır. Ön uygulama yapılan öğrenciler formda yer alan soruları genel anlamda anlaşılır bulmuşlar ve küçük birkaç değişiklik yapılarak görüşme formuna son şekli verilmiştir. Öğrenciler ile yüz yüze görüşme gerçekleştirilmiş olup, sorulara verdikleri cevaplar yazıya aktarılmıştır.

\section{Maddenin Tanecikli Yapısı ve Özellikleri Ünitesi Akademik Başarı Testi (MTYÖÜABT)}

Bu aşamada MTYÖÜABT geliştirilirken aşağıda verilen başarı testi geliştirme adımları takip edilmiştir (Kan, 2010).

a)Testin amacının belirlenmesi: Testin amacı öğrencilerin MTYÖ ünitesine ait akademik başarılarını ölçmek olarak belirlenmiştir.

b) Ölçülecek özelliğin tanımlanması, kapsamın belirlenmesi ve belirtke tablosunun oluşturulması: $\mathrm{Bu}$ aşamada öncelikle altıncı sınıf MTYÖ ünitesi kapsamında yer alan kazanımlar incelenmiştir. MTYÖ ünitesini bir önceki sene işlemiş olan yedinci sınıf öğrencilerine bu ünitede kendilerine zor gelen kazanımların belirlenmesi anketi uygulanmıştır. Bu ankete Karkamış ilçe merkezinde ve köy 
ortaokullarında, yedinci sınıflarda öğrenim gören toplam 105 öğrenci katılmış olup, anket sonucuna göre bu üniteye ait 11 kazanım belirlenmiştir.

c) Test maddelerinin oluşturulmast: Her kazanıma ait üç soru ve toplamda 33 soru çeşitli ders ve çalışma kitaplarından çoktan seçmeli olarak hazırlanmıştır.

d)Taslak maddelerin gözden geçirilmesi: Oluşturulan 33 soruluk deneme formu, maddelerin anlaşılabilirliği, her bir maddenin ölçülmek istenen kazanımı ölçebilme yeterliliği vb. kriterler açısından iki fen bilimleri öğretmeni ve dört fen eğitimi uzmanı tarafından incelenmiştir. Uzmanlar ve ögretmenlerden gelen dönütler sonucunda deneme formu üzerinde gerekli değişiklikler yapılarak form yeniden düzenlenmiştir.

e)Taslak test formunun uygulanması ve puanlanması: Başarı testine yönelik madde analizini gerçekleştirmek üzere pilot uygulama yapılmıştır. Taslak test formu aynı yedinci sınıf öğrencilerine (kendilerine zor gelen kazanımların belirlenmesi anketi uygulanmış olan 105 öğrenciye) uygulanmıştır. Puanlama yapılırken doğru cevap verilen her bir madde "1"; yanlış cevap verilen, birden çok cevap verilen ve boş bırakılan maddeler " 0 " olarak puanlanmıştır.

f)Madde analizi ve madde seçimi: Taslak test formu puanlandıktan sonra her bir maddeye ait madde güçlük indeksi ve madde ayırıcılık gücü indeksi değerleri hesaplanmıştır. Testte yer alan 11 sorunun ayırt ediciliği düşük olduğundan $\left(r_{j x} \leq 0.19\right)$ testten çıkarılmıştır. İki soru ise düzeltilip geliştirilerek $\left(0.20 \leq r_{j x} \leq 0.29\right)$ tekrar teste konmuştur (Tekindal, 2009). Ayrıca her bir maddeye ait güçlük indeksi değerlerinin ortalamasından, testin ortalama güçlügünün orta seviyede olduğu hesaplanmıştır $\left(\mathrm{p}_{j=}=0.50\right)$. Kan (2010) göre başarı testlerinde ortalama güçlüğün 0.50 civarında çıkması arzu edilen bir durumdur. Testin güvenirliğini bulmak için test maddelerinin birbiriyle olan tutarlılığına yani Kuder-Richardson (KR-20) değerine bakılması gerekir. KR-20 testin ölçtügü şeyin homojen olduğu varsayımına dayanır ve 0 ile 1 arasında bir değer alır. Bu değerin 1'e yaklaşması demek testin tesadüfi hatalardan arınık ve iç tutarlılığ yüksek olan bir test olması demektir (Tekin, 2012; Turgut ve Baykul, 2012). Bu testin KR-20 değeri ise 0,80 olarak bulunmuştur. Özbek (2010) göre başarı testlerinde güvenirlik tek başına yeterli olmayıp testin geçerliğini de bakılmalıdır. Baykul (2000) göre başarı testlerinde kapsam geçerliği aranmalıdır. Bu amaçla testin kapsam geçerliğini sağlamak adına uzman görüşüne başvurulmuş olup, uzmanlardan gelen dönütler doğrultusunda testteki maddelerin ilgili kazanımları karşılar nitelikte olduğu görülmüştür.

g) Nihai test formunun oluşturulması: Geliştirilme süreci yukarıda bahsedilen, güvenirlik ve geçerlik analizleri yapılmış olan ve 22 maddeden oluşan MTYÖÜABT, DPA oluşturulmadan önce ön test şeklinde, DPA oluşturulduktan sonra da DPA ile birlikte son test şeklinde uygulanmıştır.

\section{Maddenin Tanecikli Yapısı ve Özellikleri (MTYÖ) Ünitesinin İşleniş Süreci}

Öncelikle MTYÖ ünitesiyle ilgili içerik analizi yapılmış olup dersler bilgisayar ve projeksiyonu olan teknolojik destekli bir sınıfta işlenmiştir. Bu üniteye ait konuların işlenişinde farklı öğretim yöntem ve tekniklerin kullanılmasına ağırlık verilmiştir. Konular işlenirken çok fazla etkinlik yapılmış olup, genellikle öğrencilerin söz sahibi olduğu bir sınıf atmosferi oluşturulmaya çalışılmıştır. Araştırmacılar daha çok yönlendirici, tamamlayıcı, rehber olmuştur. MTYÖ ünitesine ait konuların işlenişine ait örnek etkinliklerden bazıları şunlardır: Örneğin Maddeyi Oluşturan Tanecikler konusunda hangi tür maddelerin daha kolay sıkıştı̆̆ını göstermek için "Hangisi Sıkışır?" etkinliği yapılmıştır. Bu etkinlikte her öğrenci üç şırınga temin etmiş, üç şırıngadan birinin içine küçük bir taş parçası, diğerine su konulmuş, üçüncüsüne de hava çekilmiş ve şırıngaların ağzı parmak ucuyla kapatılarak piston ittirilmiştir. Pistonların hareketleri ve öğrencilerin parmaklarına yaptıkları etki izlenerek hangi tür maddelerin daha kolay sıkışabileceği gözlemlenmiştir. Elementler ve Bileşikler konusunda ise öğrencilerin element, bileşik ve molekül kavramlarını daha rahat ayırt edebilmeleri için öğrencilerden renkli oyun hamurlarından element, bileşik ve molekül modelleri yapmaları istenerek bu kavramlar somutlaştırılmaya çalışılmıştır. Fiziksel ve Kimyasal Değişim 
konusunda "Maddenin Değişimi”" ve "Bir Maddeden Yeni Bir Madde Oluşur mu?" etkinlikleri yaptırılmıştır. Maddenin değişimi etkinliğinde sınıf üç gruba ayrılarak birinci gruba küp şekeri, fındık ve ceviz içlerini ayrı ayrı üç havanda ezmeleri, ikinci gruptan mumu saat camında, buzu beherglasta ve çikolatayı metal kap içerisinde hafifçe 1 sitıp eritmeleri, üçüncü gruptan ise defter kâğıdı, gazete ve kurdeleyi kesmeleri istenmiştir. Tüm grupların gözlemleri sonucunda oluşan maddelerin eskisinden farklı olup olmadığı sorulmuştur. Bu etkinlik sonucunda öğrenciler maddenin sadece dış görünümün değiştiği olaylarda maddenin fiziksel değişime uğradığını, maddenin hem iç hem de diş görünümünün değiştiği olaylarda ise maddenin kimyasal değişime uğradığ 1 sonuçlarına varmışlardır. Bir Maddeden Yeni Bir Madde Oluşur mu? etkinliğinde ise istasyon tekniği uygulanmıştır. Bu etkinlikte sınıf altı gruba ayrılarak altı öğrenme istasyonu oluşturulmuştur. Birinci istasyon mumdan bir parça keserek kestiği kısmı küçük parçalara ayırmıştır. Diğer mum parçasını ise kavanoz kapağının içerisine tutturup yakmıştır. Kestikleri mum parçalarını alüminyum tabağa koyarak ve tabağı maşayla tutturarak yaktıkları mumun alevinde 1sıtmışlardır. İkinci istasyon mumdan bir parça kesip deney tüpünün içine koymuştur. Deney tüpünü de içinde su bulunan beherglasa daldırıp sabitleştirmişlerdir. İspirto ocağını yakıp suyu 1sıtmışlar ve gözlemlerini not etmişlerdir. Üçüncü istasyon birkaç damla sirkeyi bir miktar süte ve yumurta kabuğuna damlatıp gözlemlerini not etmişlerdir. Dördüncü istasyon bir iki damla iyot çözeltisini kestiği patates dilimi üzerine damlatarak gözlemlerini not etmiştir. Beşinci istasyon kireç suyu bulunan beherglasa pipet ve gözlük kullanarak iki dakika boyunca yavaşça üfleyip gözlemlerini not etmiştir. Son olarak altınc1 istasyon da bir spatül dolusu bakır (II) sülfat $60 \mathrm{ml}$ suyun içerisine koyup karıştırmıştır. Demir çiviyi de bu karışımın içine atarak gözlemlerini not etmişlerdir. Gruplar istasyonlara dağılarak, her grup gittiği istasyonda beş dakika çalışmış ve süre sonunda gruplar yer değiştirmiştir. Böylece tüm grupların her bir istasyonda çalışması sağlanmış ve istasyona gelen her yeni grup bir önceki grubun kaldığı yerden devam etmiştir. Süre sonunda tüm gruplar toplanarak hangi grupta fiziksel, hangi grupta kimyasal değişimin olduğunu tartışmışlardır. Maddenin Hallerinin Tanecikli Yapısı konusunda ise "Kat1, Sıv1 ve Gazlarda Atomlarla Moleküller Birbirlerine Benzer mi?" etkinliğinde üç grup oluşturulmuştur. Katı haldeki maddeyi temsil eden grup tahta parçasını alarak, kol kola girip sadece titreşim hareketi yapmıştır. İkinci grup ise sıvı haldeki maddeyi temsil eden bir bardak suyu alarak, birbirine tutunmadan sürtünerek öteleme hareketi yapmıştır. Üçüncü grup ise gaz haldeki maddeyi temsil eden içi hava dolu balonu alarak sınıfın içerisine dağılmış ve koşarak hareket etmiştir. Her grubun canlandırdığı roller diğer gruplarca gözlemlenmiş, hatalı ve eksik bulunan davranışlar sınıfta tartışılmıştır. Ayrıca MTYÖÜABT, öğrencilere her dersin son 10-15 dakikasında ders boyunca işlenen konuyla ilgili olarak iki, altı ya da sekiz soruluk küçük sınavlar şeklinde ön test olarak uygulanmıştır. Verilen süre yetmediğinde bir sonraki dersin yine son 10-15 dakikasında kalınan yerden devam edilmiştir. Sorular çoktan seçmeli olduğundan öğrencilerden o cevabı neden verdiklerine dair kısa açıklamalar yapmaları istenmiştir. Açıklamayla uymayan veya açıklama yapılmayan sorular daha önce öğrencilere de söylendiği gibi yanlış kabul edilmiştir. Yapılan sınıf içi etkinlikleriyle MTYÖ ünitesinin işlenişi sekiz hafta ve toplam 32 saat sürmüştür.

\section{Dereceli Puanlama Anahtarı'nın Oluşturulması ve Kullanımı}

Öğrenciler MTYÖ ünitesinin işlenişi bittikten sonra dört ders saatlik süre içinde DPA'nın ne olduğu, ne işe yaradığı, yapısı, çeşitleri, ölçme ve değerlendirmede kullanılmasının avantajı ve dezavantajı ile ilgili araştırmacı tarafindan bilgilendirilmiştir. Bununla birlikte bu süreçte öğrencilere DPA ile ilgili somut örnekler de gösterilmiştir. Örneğin; öğrencilerin proje ödevleri değerlendirilirken kullanılan ölçekler araştırmacı tarafından öğrencilere gösterilmiş ve bu ölçeklerin de aslında bir DPA olduğu vurgulanmış ve gerçekte öğrencilerin bu ölçeklere çokta yabanc1 olmadıkları görülmüş̧ür. Ayrıca öğrenciler DPA ile ilgili merak ettiklerini araştırmacıya sormuşlardır. Araştırmacı tarafından MTYÖ ünitesiyle ilgili Maddeyi Oluşturan Tanecikler Konusu İçin Hazırlanan Bütünsel DPA, Elementler ve Bileşikler Konusu Iç̧in Hazırlanan Bütünsel DPA, Fiziksel ve Kimyasal Değissim Konusu İçin Hazırlanan Bütünsel DPA, Maddenin Hallerinin 
Tanecikli Yapısı İçin Hazırlanan Bütünsel DPA olmak üzere dört farklı bütünsel DPA hazırlanmıştır. $\mathrm{Bu}$ ünite dört farklı konu başlığından ve her konu da çok sayıda kazanımdan oluştuğundan tüm konulara uyacak veya tüm soruların değerlendirilmesinde kullanılabilecek tek bir analitik veya bütünsel DPA oluşturulamamıştır. Oluşturulan bütünsel DPA, sadece bu ünitede yer alan konular için uygulanabilecek olup, Goodrich (2001) tarafindan önerilen DPA oluşturma basamakları (performansı belirlemede kullanılacak ölçütlerin listelenmesi, puanlama stratejisi olarak hangi DPA türünün kullanılacağına karar verilmesi, performans düzeylerinin belirlenmesi ve düzey tanımlarının yapılması, uzman görüşünün alınması) dikkate alınarak araştırmacı tarafından hazırlanmıştır. Ayrıca DPA ile ilgili gerekli güvenirlik ve geçerlik çalışmaları da yapılımıştır. Boston (2002) göre bir DPA geliştirilirken geliştirilen DPA'nın güvenirliğini sağlamak adına şu sorulara mutlaka cevap aranmalıdır:

- Puanlama kategorileri iyi belirlenmiş mi?

- Puanlama kategorilerindeki farklılıklar belli mi?

- Kodlayıcılar DPA'ya göre değerlendirme yaptıklarında aynı sonucu elde edebilirler mi?

Bahsi geçen sorulara cevap aramak adına araştırmacı tarafından puanlama kategorileri belirlenmiş ve bu belirleme sürecinde uzman görüşüne de başvurulmuştur. Kodlayıcılar arası güvenirliği belirlemek için de DPA kullanılmadan çözülen ön test soruları ve DPA kullanılarak çözülen son test soruları, öncelikle araştırmacı tarafından DPA'ya göre değerlendirilmiştir. Daha sonra ise benzer şekilde rastgele seçilen üç öğrenci tarafından, kura yoluyla seçilen üç öğrencinin ön ve son testleri DPA'ya göre değerlendirilmiştir. Sınıf seviyesi düşük olduğundan ve değerlendirme süreci çok uzun sürdüğünden, bu süreç öğrencilerden üç değerlendirmeci ve değerlendirilen üç öğrencinin ön ve son testleriyle sinırlı tutulmuştur. Böylelikle akran değerlendirilmesine de firsat verilmiştir. Değerlendirme sonucunda araştırmacının ve öğrencilerin verdiği puanların birbirine yakın olduğu görülmüştür. Böylece kodlayıcılar arası güvenirlik de sağlanmıştır. Oluşturulan DPA'nın geçerliği sağlamak için de ölçüt, yap1 ve içerlik geçerliğine bakılmıştır (Boston, 2002). Araştırmacı tarafından oluşturulan bu DPA'ların MTYÖ ünitesiyle ilgili soru çözümlerinde kullanılacağı, çözdükleri soruların bu DPA'lara göre ve her bir sorunun 100 puan üzerinden değerlendirileceği araştırmacı tarafından öğrencilere izah edilmiştir. Daha sonra ise her fen dersinin son 10-15 dakikasında MTYÖ ünitesinin işlenişi süresince ön test olarak uygulanan 22 soru, son test olarak da uygulanmıştır. Fakat bu sefer bu sorularla birlikte araştırmacı tarafindan hazırlanan DPA'lar dağıtılmış ve öğrencilerden soruları bu DPA'lara göre çözmeleri istenmiştir.

\section{Verilerin Analizi}

\section{Nicel Bulguların Analizi}

Öğrencilerin MTYÖ ünitesiyle ilgili soruları çözme başarılarının DPA kullanımına bağlı olup olmadığıyla ilgili yapılan istatistiksel analiz için bağımlı iki örnek t-Testi ( paired samples tTest) kullanılmıştır. Öğrencilerin DPA kullanımına bağlı olarak ünite ile ilgili problemleri çözmedeki başarıları ile cinsiyet arasında ilişki olup olmadığıyla ilgili istatistiksel analizlerde ise bağımsız iki örnek t-Testi (independent samples t-Test) kullanılmıştır.

\section{Nitel Bulguların Analizi}

Nitel bulguların analizinde içerik analizi yöntemi kullanılmıştır. Bu analiz türünde yapılan temel işlem; benzer olan verileri belirli kavramlar ve temalar etrafinda toplayarak bunları okuyucunun anlayacağ ş̧ekilde düzenleyip yorumlamaktır (Yıldırım ve Şimşek, 2006). Bu amaçla öncelikle araştırmacılar tarafından her bir görüşme sorusu için kodlar oluşturulmuştur. Daha sonra ise Miles ve Huberman (1994) tarafindan ortaya konan güvenirlik formulü (Görüş Birliği/(Görüş Birliği+Görüş Ayrılığı)x100) kullanılarak araştırmacılar arasındaki uyum oranı belirlenmeye çalışılmış ve hesaplamalar sonucunda bu oran \%90 bulunmuştur. Yıldırım ve Şimşek (2011) göre bu 
yüzdenin $\% 70$ ve üzerinde olması verilerin analiz güvenirliği için yeterli sayılmaktadır. Bu çalışmada asıl ortaya konulmak istenen temel tema; "Ön ve Son Test Sorularının DPA'ya Göre Değerlendirme Sürecinin Değerlendirilmesidir." Oluşturulan kodlar çerçevesinde ise şu kategoriler (temalar) ortaya çıkmıştır.

$>$ DPA'nın Konuyu Kavramadaki Etkisi

$>$ DPA'nın Problem Çözümüne Etkisi

$>$ DPA'nın Öğrenmeye Etkisi

DPA Verilmesinin Avantajları

\section{Bulgular}

\section{Nicel Bulgular}

Öğrencilerin DPA kullanımı sonrasındaki MTYÖ ünitesindeki soruları çözme başarıları DPA kullanımı öncesindeki başarılarına göre anlamlı bir farklılık göstermekte midir? problemi ile ilgili elde edilen bulgular Tablo 2'de verilmiştir.

Tablo 2: DPA Kullanımına Bağlı Olarak Ön ve Son Test Puanlarının t-Testi Sonuçları

\begin{tabular}{lcccccc}
\hline Ölçüm (DPA) & $N$ & $\bar{X}$ & $S$ & $s d$ & $t$ & $p$ \\
\hline Ön test toplam & 25 & 918 & 17.37 & 24 & 8.2 & .000 \\
\hline Son test toplam & 25 & 1682 & 18.43 & & & \\
\hline
\end{tabular}

Tablo 2 incelendiğinde öğrencilerin DPA kullanmadan çözdükleri soruların (ön test) puan ortalamasının $(\bar{X}=918)$, öğrencilerin DPA kullanarak çözdükleri soruların (son test) puan ortalamasından $(\bar{X}=1682)$ daha düşük olduğu görülmektedir. Bu sonuca göre öğrencilerin ön ve son test puanları arasında anlamlı bir farklılık olduğu bulunmuştur $(p<.05)$. Bu bulgu, öğrencilerin MTYÖ ünitesindeki soruları çözme başarılarında DPA kullanımıyla anlamlı bir artış olduğunu göstermektedir.

Araştırmanın ikinci problemi olan öğrencilerin DPA kullanımı ile MTYÖ ünitesiyle ilgili problemleri çözmedeki başarıları ile cinsiyet arasında anlamlı bir ilişki var mıdır? problemi ile ilgili istatistiksel bulgular Tablo 3' de verilmiştir.

Tablo 3: Öğrencilerin MTYÖ Ünitesi İle İlgili Problem Çözmedeki Başarılarının Cinsiyete Göre Değişiminin t-Testi Sonuçları

\begin{tabular}{cccccccc}
\hline & Cinsiyet & $N$ & $\bar{X}$ & $S$ & $s d$ & $t$ & $p$ \\
\cline { 2 - 8 } Ön test & $\mathrm{K} 1 \mathrm{z}$ & 14 & 43.01 & 16.39 & 23 & .484 & .633 \\
toplam & Erkek & 11 & 40.07 & 13.14 & & & \\
\hline $\begin{array}{c}\text { Son test } \\
\text { toplam }\end{array}$ & $\mathrm{K} 1 \mathrm{z}$ & 14 & 80.19 & 11.60 & 23 & 1.14 & .265 \\
\hline
\end{tabular}

Tablo 3 incelendiğinde öğrencilerin MTYÖ ünitesi ile ilgili problem çözmedeki başarıları ön ve son testte cinsiyete göre anlamlı bir farkl1lık göstermemektedir $(p>.05)$. Kızların ön testte aldıkları toplam ortalama puanlar $(\bar{X}=43.01)$ ile erkeklerin ön testte aldıkları toplam ortalama puanlar $(\bar{X}=40.07)$ birbirine çok yakındır. Benzer şekilde kızların son test toplam ortalama puanları $(\bar{X}=80.19)$ ile erkeklerin son test toplam ortalama puanları $(\bar{X}=71.68)$ arasinda büyük farkl11ık gözlenmemiştir. 


\section{Nitel Bulgular}

Çalışmanın nitel bulguları yarı yapılandırılmış görüşme formundan elde edilen verilerin analizi yapılarak oluşturulmuştur. Bu bulgular dört kategorik başlık altında verilmiştir. Bu kategoriler ise öğrencilerin görüşme sorularına verdikleri cevaplardan oluşturulan kodları içermektedir. Ana tema etrafında oluşturulan kategoriler ve bu kategorilere ilişkin kodlar Tablo 4'de verilmiştir.

Tablo 4. Çalıșmada Elde Edilen Kategoriler ve Kategorilere İlişkin Kodlar

\begin{tabular}{llr}
\hline Kategoriler & Kodlar & $\mathrm{f}$ \\
\hline DPA'nın Konuyu Kavramadaki Etkisi & Maddenin hallerinin özelliklerini anlama & 2 \\
& Maddenin nereye kadar bölünebileceğini sorgulama & 1 \\
& Element ve bileşiği ayırt etme ipuçları & 1 \\
& Fiziksel ve kimyasal değişimlerde maddenin yapısını gözlemleme & 3 \\
& & 2 \\
DPA'nın Problem Çözümüne Etkisi & Problem çözme becerisini geliştirmesi & 3 \\
& Problem çözümünde rehber olması & 3 \\
DPA'nın Öğrenmeye Etkisi & Kalıcı öğrenme sağlaması & 2 \\
DPA Verilmesinin Avantajları & Problem çözümünün her aşamasının dikkate alınması & 2 \\
\hline
\end{tabular}

\section{a) DPA'nın Konuyu Kavramadaki Etkisi}

Çalışmaya katılan öğrencilere araştırmanın ilk sorusu olarak "MTYÖ ünitesi ile ilgili size verilen soruları önce DPA kullanmadan, sonra ise DPA kullanarak çözdünüz. Sizce DPA'nın ünitedeki konuları kavramınızda size katkısı oldu mu?" sorusu sorulmuştur. Bu soruya öğrencilerin verdikleri cevaplara göre; Maddenin Hallerinin Özelliklerini Anlama, Maddenin Nereye Kadar Bölünebileceğini Sorgulama, Element ve Bileşiği Ayırt Etme Ípuçları, Fiziksel ve Kimyasal Değişimlerde Maddenin Yapısını Gözlemleme kodları oluşturulmuştur. Bu kodlara ilişkin bazı öğrenci görüşleri aşağıdaki gibidir:

\section{Maddenin Hallerinin Özelliklerini Anlama}

Ö:: "Bu ünitede DPA'nın konuyu kavramamda etkisi oldu. Çünkü DPA sayesinde katıların, sıvıların ve gazların özelliklerinin birbirinden farklı olduğunu daha iyi kavradım."

Ö7: "Soru çözerken katı, sıvı ve gazların tanecik yapılarını hiç düşünmediğimden soruları hep yanlış çözerdim. Oysaki DPA bana soru çözerken katı, sıvı ve gazların tanecik yapılarına dikkat etmem gerektiğini hatırlattı. DPA sayesinde katı, sıvı ve gazların tanecik yapılarından neleri daha kolay yapacaklarını veya neleri daha kolay yapamayacaklarını daha iyi kavradım."

\section{Maddenin Nereve Kadar Bölü̈nebileceğini Sorgulama}

Ö: "DPA'nın bu üniteyi kavramamda etkisi olduğuna inanıyorum. DPA kullanmadan maddeyi hep bir bütün olarak düşünürdüm. Oysaki DPA, maddelerin görünmez küçük parçalardan oluştuğunu ve nereye kadar ardışık bölünebileceğini düşünmemi sağladı.” 


\section{Element ve Bilesiği Avurt Etme İpuclart}

Ö : "Elbette DPA'nın bu üniteyi kavramamda çok büyük katkısı oldu. Element ve bileşiği ayırt etmede çok zorlanıyordum fakat DPA bana element ve bileşiği ayırt edebilmemin tüm ipuçlarını veriyordu. Bu ipuçları da bu konuyu daha iyi kavramamı sağladı. Şuan element ve bileşik sorularını çözmek bana çok eğlenceli geliyor.

\section{Fiziksel ve Kimvasal Değisimlerde Maddenin Yapısını Gözlemleme}

Ö : “DPA harika bir şey. Bir konunun önemli kavramları onun içinde saklı. Özellikle bu ünitede bir maddenin değişerek başka bir maddeye dönüşebileceğini bana kavrattı ve bir maddenin değişerek başka bir maddeye dönüştüğü olaylara DPA sayesinde şimdi daha güzel örnekler verebiliyorum."

Ö5: "DPA'nın bu üniteyle ilgili bazı temel kavramları kavramamda çok büyük etkisi olduğuna inanıyorum. Kimyasal değişimlerde maddenin kimliğinin de değiştiğini DPA sayesinde kavradım. DPA sorulara farklı açıdan bakmam gerektiğini bana öğretti. Örneğin kimyasal değişim sorularında, kimyasal değişim deyince aklıma maddenin kimliği geliyor. Bunu da DPA'ya borçluyum.”

Ö6: "DPA'nın kesinlikle bu üniteyi kavramamda büyük katkısı oldu. Fiziksel ve kimyasal değişimleri ayırt edemezken DPA bunları ayırt etmemin ipuçlarını bana verdi. İlk testte fiziksel ve kimyasal değişimi tam ayırt edemediğimden fiziksel ve kimyasal değişim sorularına yanlış cevap vermiştim. Ama DPA ile verilen son testte DPA bana rehber oldu ve fiziksel ve kimyasal değişimi kolayca birbirinden ayırt etmemi sağladı. DPA sayesinde kendime güvenim geldi. Fiziksel ve kimyasal değişim soruları korkulu rüyamken, DPA sayesinde en sevdiğim soru tipleri haline geldi."

$\mathrm{Bu}$ kategori çerçevesinde öğrencilerin görüşlerine bakıldığında; öğrencilerin MTYÖ ünitesinde yer alan konuları kavramalarında DPA'nın büyük bir katkısı olduğu görülmektedir. Öğrenciler DPA sayesinde katıların, sıvıların ve gazların özelliklerini, element-bileşik ve fizikselkimyasal değişimleri ayırt ettiklerini ve DPA olmadan çözdükleri testlerde bunları ayırt etmekte zorluk çektiklerini ifade etmişlerdir. Ayrıca öğrencilere göre DPA soru çözmeyi eğlenceli hale getirmektedir. Öğrencilerin son test puanlarının ön test puanlarına göre yüksek olması da öğrencilerin ünitede yer alan konuları kavramasında DPA'nın katkısı ile ilgili sorulan sorulara verdikleri cevapları destekler niteliktedir.

\section{b) DPA’nın Problem Çözümüne Etkisi}

Çalışmaya katılan öğrencilere araştırmanın ikinci sorusu olarak “Problem çözerken DPA'y1 kullanmanız ile kullanmamanız arasında ne gibi farklılıklar ortaya çıktı? DPA problem çözümünde size yardımcı oldu mu" sorusu sorulmuştur. Bu soruya öğrencilerin verdikleri cevaplara göre Problem Çözme Becerisini Geliştirmesi, Problem Çözümünde Rehber Olması kodları oluşturulmuştur. Bu kodlara ilişkin bazı öğrenci görüşleri aşağıdaki gibidir:

\section{Problem Ç̈̈zme Becerisini Geliștirmesi}

Ö2: "Not açısından bakarsam bana çok katkısı oldu. Çünkü neyi yaparsam kaç puan alacağımı biliyordum ve DPA sayesinde konuyu anlamak çok kolay oluyor. Sadece sonuca puan verilmemesi bize o konuyla ilgili bildiklerini ifade etme şansı tanıyor. Kısacası DPA’nın problem çözme becerimi geliştirdiğini düşünüyorum.”

Ö : "Diğer konularda soru çözümünde nereden başlayacağım ve nasıl yapacağım konusunda zorlanıyordum. Ama DPA kullanarak çözdüğüm sorularda, soru çözümüne nereden başlayacağım ve nasıl yapacağım apaçık ortadaydı. DPA'nın problem çözme becerimi geliştirdiğini düşünüyorum.” 


\title{
Problem Cözümünde Rehber Olmast
}

\begin{abstract}
Ö6: "DPA kullanarak girdiğim son testten DPA kullanmadan girdiğim ilk teste göre daha yüksek puan aldım. Bence her ünitede DPA kullanılmalı. DPA problem çözümümde adeta bana rehber oldu."

Ö$_{1}$ : "Bence her konu için DPA oluşturulmalı. Yüksek not almak için sadece sonuca bakılmaması, aynı zamanda problemi çözerken yaptıklarımın da önemli olması bence çok önemli. Problem çözümünde bana çok katkısı oldu. Neyi neye göre yapacağımı bildiğim için yavaş yavaş sonuca nasıl ulaşacağımı öğrenmemde bana yardımcı oldu."

Ö$_{3}:$ "DPA problem çözümünde bana çok yardımcı oldu. DPA kullanmadan girdiğim sınavla DPA kullanarak girdiğim sınavdan aldığım puan arasında çok fark vardı. DPA'da verilen aşamalara göre soru çözümüne gidersem sonuca daha rahat ulaşabileceğimi fark ettim."
\end{abstract}

$\mathrm{Bu}$ kategori çerçevesinde öğrencilerin görüşlerine bakıldığında; DPA'nın problem çözümüne büyük katkısı olduğu görülmektedir. Ayrıca öğrenciler DPA'nın problem çözme becerilerini geliştirdiğini, sonuca daha az hatayla ulaştıklarını dolayısıyla son sınavdan aldıkları puanların arttığını ifade etmişlerdir. Bunların yanı sıra öğrenciler DPA'nın soru çözümüne nereden ve nasıl başlayacakları konusunda yardımcı olduğunu, kısacası problem çözümünde DPA'nın onlara adeta bir rehber olduğunu belirtmişlerdir. Bununla birlikte sadece sonuca değil de, problem çözümünün her aşamasına puan verilmesinin öğrencilerin o konuyla ilgili bildiklerini rahat ifade etme şansı verdiği de görülmektedir.

\section{c) DPA'nın Öğrenmeye Etkisi}

Çalışmaya katılan öğrencilere araştırmanın üçüncü sorusu olarak "DPA'nın öğrenme üzerindeki etkisi hakkında ne düşünüyorsunuz?” sorusu sorulmuştur. Bu soruya öğrencilerin verdikleri cevaplara göre Kalıcı Öğrenme Sağlaması kodu oluşturulmuştur. Bu kodlara ilişkin bazı öğrenci görüşleri aşağıdaki gibidir:

\section{Kalıcı Öğrenme Să̆glaması}

Ö$_{2:}$ "Bence DPA'nın öğrenmede kalıcılığa etkisi çok. Örneğin elementler ve bileşikler konusunu kavramamda DPA bana çok yardımcı oldu. Ön testte element ile bileşiği çok karıştırdığımdan bunla ilgili soruları yanlış çözmüş̧üm. Ama DPA ile birlikte verilen son testte element ve bileşiği ayırt etmemin tüm ipuçları saklıydı. Bu ipuçları sayesinde element ve bileşik sorularını doğru çözdüm ve aradan kaç ünite geçerse geçsin element ve bileşiği kolay kolay unutacağımı zannetmiyorum. DPA sayesinde öğrendiklerim daha kalıcı oldu."

Ö5: "DPA'nın öğrenmede kalıcılığa katkısı çok. Fiziksel ve kimyasal değişimleri ayırt etmekte çok zorlanıyordum. Ama DPA sayesinde kimyasal değişim deyince aklıma ilk maddenin kimliği geliyor. Böylece bu soruları daha rahat çözebiliyorum. Bu konuyu iyi kavradığımı düşünüyorum ve kolay kolay da unutacağımı zannetmiyorum.”

Ö$_{7}$ : "Her iki testte aynı olmasına rağmen, DPA kullanmadan çözdüğüm ön testlerde hem çok zorlandım hem de öğrendiklerim pek aklımda kalmadı. Oysaki DPA kullanarak çözdüğüm son testlerde adeta çözerken öğrendim ve öğrendiklerimin kalıcı olduğuna inanıyorum. Eğer öğrenmede kalıcılık isteniyorsa bence DPA tüm derslerde ve tüm konularda kullanılmalı."

$\mathrm{Bu}$ kategori çerçevesinde öğrencilerin görüşlerine bakıldığında; görüşmeye katılan öğrencilerin hepsi DPA’nın kalıcı öğrenme sağladığı görüşündedirler. Özellikle öğrenciler ön test ile son test sorularının aynı olmasına rağmen ön testten çıktıktan sonra akıllarında pek bir şey kalmadığını son testten çıktıktan sonra ise çoğu şeyi hatırladıklarını ifade etmişlerdir. Ayrıca DPA sayesinde element-bileşik kavramlarını ve fiziksel-kimyasal değişim sorularını daha rahat ayırt edebildiklerini ve bu farklılıkları kolay kolay unutmayacaklarını ifade etmişlerdir. Ayrıca öğrenciler 
aradan kaç ünite geçerse geçsin MTYÖ ünitesine ait konuların akıllarından kolay kolay silinmeyeceğini, eğer öğrenmede kalıcılık isteniyorsa DPA'nın tüm derslerde ve konularda kullanılması gerektiği düşüncesindedirler.

\section{d) DPA Verilmesinin Avantajları}

Çalışmaya katılan öğrencilere araştırmanın dördüncü sorusu olarak "Bir ödev verilirken veya bir problem çözülürken DPA'nın da verilmesinin size göre avantajı ve dezavantajı nelerdir?" sorusu sorulmuştur. Bu soruya öğrencilerin hepsi bir ödev verilirken veya bir problem çözerken DPA'nın da verilmesinin dezavantajının olmadığını ifade ettiklerinden DPA verilmesinin avantajları üzerine yoğunlaşılmıştır. Dolayısıyla öğrencilerin sorulara verdikleri cevaplara göre Problem Çözümünün Her Aşamasının Dikkate Alınması, Bilenle Bilmeyeni Ayırt Etmesi kodları oluşturulmuştur. Bu kodlara ilişkin bazı öğrenci görüşleri aşağıdaki gibidir:

\section{Problem Cözümünün Her Asamasının Dikkate Alınması}

Ö: "Konuları kavramamız açısından bence olumlu etkisi var. Problem çözümünde sadece sonuca puan verilmemesi, o sonuca ulaşırken yaptığımız her şeyin puanlandırılması bence çok güzel. Örneğin bir problem çözerken en ufak işlem hatası yaptığımızda sonuç yanlış çıktı̆ı̆ında sıfır puan alıyorduk. Oysaki DPA'ya göre kâğıtlarımız değerlendirildiğinde işlem hatasına kadar olan kısımdan da puan aldığımızdan sıfır puan almıyorduk. Bence hiçbir dezavantajı yok."

$\ddot{O}_{7}:$ "Direk sonuca puan vermek yerine işlemlere aşama aşama puan verilmesi bence başarılı öğrenciler için avantajlı. Ama sadece sonuca odaklanan öğrenciler için DPA dezavantaj. DPA yapılan her işleme aşama aşama puan verdiğinden sonuç doğru olsa bile sonuca ulaşmak için yapılan işlemler yanlış olursa öğrenci yüksek puan alamıyordu.”

\section{Bilenle Bilmeyeni Ayurt Etmesi}

$\ddot{O}_{3}$ : 'Bence DPA'nın avantajı çok. Çünkü bilenle bilmeyeni ayırt ediyor. Sonuca ulaşmak için yaptığın her şeyden puan almak bence çok güzel bir şey. Yapacağımız her şeyin puanlandırılması problemi daha dikkatli çözmemizi sağlıyor. Değerlendirmenin sadece öğretmene göre değil de ortak bir puanlama anahtarına göre olması bence çok avantajlı bir durum."

Ö$_{4}$ : “DPA'nın bana göre avantajı çok. Değerlendirmeci ister öğrenci olsun ister öğretmen olsun değerlendirme yaparken hangi bölüme kaç puan verileceği gibi kafamızda soru işaretleri oluşmuyor. Böylece herkese adil davranıliyor. Sadece sonuca odaklanan öğrenciler için dezavantajı olabilir ama gerçekten bilenle bilmeyeni ayırt edebilen bir puanlama anahtarı."

$\mathrm{Bu}$ kategori çerçevesinde öğrencilerin görüşlerine bakıldığında; öğrenciler bir ödev verilirken veya bir problem çözülürken DPA'nın da verilmesinin birçok avantajı olduğunu ifade etmişlerdir. Öğrencilere göre bu avantajlar; DPA'nın sadece doğru sonuca odaklı bir değerlendirme aracı olmaması, problem çözümünde her aşamanın puanlandırılması dolayısıyla her aşamanın öğrenciye puan kazandırması, bir öğrencinin gerçekten o konuyu anlayıp anlamadığını ortaya çıkarması yani değerlendirmeyi tesadüfi hatalardan uzaklaştırması ve adil bir puanlama anahtarı olmasidir.

\section{Sonuç ve Tartışma}

Alternatif (tamamlayıcı) ölçme değerlendirme teknikleri sadece öğrencinin bilgi seviyesini ölçmekte kalmayıp onların çok yönlü gelişimlerini (yaratıcılık, öz eleştiri becerileri vb.) destekleyen bir tekniktir. Bu çalışmada da ortaokul altıncı sınıf öğrencilerinin seçilen bir üniteye (Maddenin Tanecikli Yapısı ve Özellikleri) ait konuları öğrenmelerinin değerlendirilmesinde çağdaş ölçmedeğerlendirme araçlarından biri olan DPA kullanılmıştır. Çalışma verilerinden elde edilen nicel bulguların ortaya koyduğu sonuçlara bakıldığında, öğrencilerin MTYÖ ünitesine ait soruları 
çözerken DPA kullanmalarının başarılarını önemli oranda artırdığı görülmüştür. Bu bulgu, DPA'nın değerlendirme yöntemi olarak kullanıldığı çalışmalarla (Aytaç, 2006; Tuncel, 2011; Neukom, 2000; Martinez, 1997) benzerlik göstermektedir. Aytaç (2006) yaptığı bir çalışmada değerlendirme yöntemi olarak DPA kullanılmasının öğrencilerin başarısını artırdığını ve değerlendirme sonuçları bakımından daha güvenilir bulguların ortaya çıktığını görmüştür. Tuncel (2010) yaptığı çalışmanın sonucunda sosyal bilgiler dersinde rubrik (DPA) kullanmanın etkili bir değerlendirme aracı olduğunu ifade etmiştir. Neukom (2000) yaptığı çalışmasında ise ödevleri değerlendirmek için rubrik (DPA) kullanmış ve öğrenmenin olumlu yönde etkilendiğini görmüştür. Martinez (1997) tarafindan yapılan bir çalışmada ise rubrik (DPA) kullanan yani değerlendirme ölçütlerden haberdar olan bir sınıfın yazma ödevlerinde daha başarılı olduğu sonucuna ulaşılmıştır. Ayrıca cinsiyet türünün öğrencilerin aldıkları puanlarda bir etken olmadığı sonucuna ulaşılmıştır.

Nitel bulguların ortaya koyduğu sonuçlara bakıldığında, bu sonuçlar alan yazındaki birçok çalışmanın sonuçlarıyla benzerlik göstermektedir. Nitel bulgulardan elde edilen sonuçlara göre öğrenmelerin değerlendirilmesinde DPA kullanmanın ve değerlendirme ölçütlerinin önceden bilinmesinin önemli olduğu (Erman Aslanoğlu ve Kutlu, 2003), DPA'nın öğretmen ve öğrenciye rehberlik ettiği, DPA sayesinde öğrencilerin değerlendirme ölçütlerinden haberdar olduğu, değerlendirmede zaman kaybını azalttığı (Mullen, 2003), öğrenci anlamalarının değerlendirilmesinde önemli olduğu (Saxe ve diğ., 1999), öğrencilerin öğrenmelerini kolaylaştırdığı ve öğrenci öğrenmesine olumlu yönde katkıda bulunduğu (Vaughn, 2002) sonuçları ortaya çıkmıştır. Bununla birlikte öğrencilerin MTYÖ ünitesi ile ilgili çözdükleri sorular DPA'ya göre değerlendirildiği için daha adil ve tutarlı değerlendirme sonuçları elde edilmiştir. Bu sonuç Luft (1999) tarafından yapılan bir çalışmanın sonucuyla benzerlik göstermektedir. Luft'un yaptığı çalışmanın sonucunda her konuya göre DPA oluşturmak zaman kaybına sebep olsa da DPA'nın değerlendirme sürecini daha adil ve kısa hale getirdiği görülmüştür. DPA'nın öğrenme eksikliklerini ortaya çıkardığı ve öğrencinin bir sınavdan kaç puan alacağını hem öğretmen hem de öğrenci açısından tahmin etme firsatı verdiği görülmüştür. Bu sonuç Kurt ve İzmirli (2010) tarafından yapılan çalışmanın sonucuyla benzerlik göstermektedir. Öğretim Teknolojileri Materyal Geliştirme dersinde öğrenci ürünlerinin değerlendirilmesinde DPA kullanılan çalışmanın sonucunda DPA'da yer alan ölçütlerin öğrenciler tarafından önceden bilinmesinin öğrencilerin alacakları notu tahmin etmesini sağlayacağ 1 sonucuna ulaşılmıştır. Güneş ve Soran (2013) tarafindan yapılan bir çalışmanın sonucuna göre ise öğrenciler çalışmalarında DPA'ya bağlı kalmaktan hoşlanmadıklarını, DPA'ya bağlı kalarak çalıştıklarında ise sadece öğretmen isteklerini yerine getirmek zorunda kaldıklarını dolayısıyla yaratıcılıklarının engellendiğini ve ödevlerinin DPA'ya göre objektif bir şekilde değerlendirilmesinden rahatsızlık duyduklarını ifade etmişlerdir. Araştırma sonuçlarındaki bu farklılık çalışma gruplarının farklı olmasından kaynaklanabilir. Bu araştırmadan elde edilen sonuçlar doğrultusunda şu önerilere yer verilebilir:

1. Sınav kâğıtlarının DPA ile değerlendirilmesi yapılırken, öğretmen değerlendirmesinin yanı sira öz ve akran değerlendirme de yapılabilir.

2. Öğretmenin bir konuyu veya proje ödevini değerlendirirken kendi veya öğrencileri ile beraber hazırladığı DPA'yı kullanması daha etkili olabilir. Böylece öğrenciler DPA'y1 oluşturan ölçütleri, kriterleri ve puanları daha iyi yorumlayabilir, bir problemi DPA'ya göre daha rahat çözebilir veya bir proje ödevini DPA'ya göre daha rahat hazırlayabilir.

3. DPA hakkında aileler de bilgilendirilmelidir. Çünkü öğretmenler özellikle proje ödevlerinde öğrencilerin nasıl ve neye göre değerlendirildiklerini ailelerine anlatırken DPA'lar somut deliller sağlayabilir.

4. Öğretmen, öğrenci ve velileri alternatif ölçme ve değerlendirme teknikleri konusunda bilinçlendirmek için MEB tarafından eğitici seminerler düzenlenebilir. 
5. MEB tarafından öğrenci başarısının ve proje ödevlerinin değerlendirilmesinde DPA kullanılması teşvik edilebilir. Ayrıca öz ve akran değerlendirmesini teşvik edecek çalışmalar da yapılabilir.

\section{Kaynakça}

Aytaç, N. (2006). Üniversite öğrencilerinin Newton'un hareket yasalarını anlamalarının değerlendirilmesinde dereceli puanlama anahtarı geliştirilmesi ve kullanımı (Tez No. 177947) [Yüksek lisans tezi, Balıkesir Üniversitesi]. Yükseköğretim Kurulu Ulusal Tez Merkezi.

Baykul, Y. (2000). Eğitimde ve psikolojide ölçme: Klasik test teorisi ve uygulaması ÖSYM Yayınlar1.

Birel, A. S. ve Albuz, A. (2014). Viyolonsel öğretiminde performans1 değerlendirmeye yönelik hazırlanan dereceli puanlama anahtarının (rubrik) sınanması ve değerlendirilmesi. Atatürk Üniversitesi Sosyal Bilimler Enstitüsü Dergisi, 18(3), 181-207. https://doi.org/10.17556/erziefd.341456

Boston, C. (2002). Understanding scoring rubrics: A guide for teachers. ERIC Clearinghouse on Assessment and Evaluation.

Brookhart, S. M. (1999). Teaching about communicating assessment results and grading. Educational Measurement: Issues and Practice, 18(1), 5-13. https://doi.org/10.1111/j.17453992.1999.tb00002.x

Büyüköztürk, Ş., Çakmak, E. K., Akgün, Ö.E., Karadeniz, Ş. ve Demirel, F. (2008). Bilimsel araştırma yöntemleri. Pegem Yayıncılık. https://doi.org/10.14527/9789944919289

Creswell, J. W. (2009). Research design: Qualitative, quantitative and mixed methods approaches. Sage Publishing.

Creswell, J. W. (2017). Research design: Qualitative, quantitative and mixed methods approaches (S. B. Demir, Çev.). Girişim Yayıncılık.

Creswell, J. W. ve Plano-Clark, V. L. (2007). Designing and conducting mixed methods research. Sage Publishing.

Çoruhlu, Ş. T., Nas, E. S. ve Çepni, S. (2009). Fen ve teknoloji öğretmenlerinin alternatif ölçme değerlendirme tekniklerini kullanmada karşılaştıkları problemler: Trabzon örneği. Yüzüncü Yll Üniversitesi Ë̆itim Fakültesi Dergisi, 6(1), 122-141. https://doi.org/10.17860/mersinefd.301633

Erman Aslanoğlu, A. ve Kutlu Ö. (2003). Öğretimde sunu becerilerinin değerlendirilmesinde dereceli puanlama anahtarı (rubric) kullanılmasına ilişkin bir araştırma. Ankara Üniversitesi Eğitim Fakültesi Dergisi, 36(1-2), 25-36. https://doi.org/10.1501/egifak_0000000078

Goodrich Andrade, H. (2001, April 17). The effects of instructional rubrics on learning to write. Current Issues in Education [On-line], 4 (4). Available: http://cie.ed.asu.edu/volume4/number4/.

Green, J. C., Krayder, H. ve Mayer, E. (2005). Combining qualitative and quantitative methods in social inquiry. In B. Somekh \& C. Lewin (Eds.), Research methods in the social sciences (pp. 275-282). Sage Publishing.

Güneş, P. ve Soran, H. (2013). İlköğretim ikinci kademe öğrencilerinin dereceli puanlama anahtarına ilişkin görüşleri. Kastamonu Eğitim Dergisi, 21(4), 327-1344. https://doi.org/10.24106/kefdergi.2559 
Haladyna, T. M. (1997). Writing test items to evaluate higher order thinking. Allyn and Bacon.

Kan, A. (2010). Ölçme aracı geliştirme. S. Tekindal (Ed.), Eğitimde ölçme ve değerlendirme (ss. 240-274). Pegem Yayınc1lik. https://doi.org/10.14527/9786055885168.08

K1lıç, S. (2013). Örnekleme yöntemleri. Journal of Mood Disorders, 3(1), 44-46.

Krajcik, J. S., Czerniak, C. M. ve Berger, C. (1999). Teaching children science: A project-based approach. McGraw-Hill.

Kurt, A. A. ve İzmirli, S. (2010). Dereceli puanlama anahtarı ile materyal değerlendirmesine ilişkin öğretmen adaylarının görüşleri. Ë̆itim Teknolojileri Araştırmaları Dergisi, 1(3), 1-19. https://doi.org/10.21764/efd.93792

Kutlu, Ö., Yıldırım Ö. ve Bilican S. (2009). Öğretmenlerin dereceli puanlama anahtarlarına ilişkin tutum ölçeği geliştirme çalışması. Yüzüncü Yll Üniversitesi Eğitim Fakültesi Dergisi, 6(2), 76-88. https://doi.org/10.17860/mersinefd.550687

Luft, J. A. (1999). Rubrics: Design and use in science teacher education. Journal of Science Teacher Education, 10(2), 107-121. https://doi.org/10.1023/a:1009471931127

Martinez, K. (1997). The effect of a rubric on evaluating and improving student writing. Published Thesis, Caldwell College, New Jersey.

Marzano, R. J., Pickering, D. ve Mctighe, J. (1993). Assess student outcomes: Performance assessment using dimensions of learning model. Association for Supervision and Curriculum Development.

Merriam, S. B. (2013). Nitel araştırma desen ve uygulama için bir rehber. Nobel Yayıncılık.

Miles, M. B. ve Huberman, A. M. (1994). Qualitative data analysis: An expanded sourcebook (2nd ed.). Sage Publishing.

Milli Eğitim Bakanlığı Talim ve Terbiye Kurulu Başkanlığı (2005). Illköğretim fen ve teknoloji dersi ögretim programı (6. $7 . \quad 8 . \quad$ sinıflar). Milli Eğitim Bakanlığı. https://doi.org/10.29329/mjer.2019.218.11

Milli Eğitim Bakanlığı Talim ve Terbiye Kurulu Başkanlığı (2013). Illköğretim fen ve teknoloji dersi ögretim programı (6. $7 . \quad 8 . \quad$ sinıflar). Milli Eğitim Bakanlığı. https://doi.org/10.29329/mjer.2019.218.11

Mullen, Y. K. (2003). Student improvement in middle school science. Master Thesis, Wisconsin Oshkosh University, Wisconsin.

Neukom, J. R. (2000). Alternative assessment: Rubrics-students' self assessment process. Master Thesis, The Faculty of Pacific Lutheran University, U.S.A.

Özbek, Ö. Y. (2010). Ölçme araçlarında bulunması istenen nitelikler. S. Tekindal (Ed.), Eğitimde ölçme ve değerlendirme (ss. 43-89). Pegem Yayınc1lık. https://doi.org/10.14527/9786055885168.03

Popham, W. J. (2000). Modern educational measurement (3rd ed.). Prentice-Hall.

Saxe, G. B., Gearhart, M., Franke, M. L., Howard, S. ve Crockett, M. (1999). Teachers' shifting assessment practices in the context of educational reform in mathematics. Teaching and Teacher Education, 15(1), 85-105. https://doi.org/10.1016/s0742-051x(98)00032-8

Schirmer, B. R. ve Bailey, J. (2000). Writing assessment rubric: An insructional approach with struggling writers. Teaching exceptional children, 33(1), 52-58. https://doi.org/10.1177/004005990003300110 
Silverman, D. (2006). Interpreting qualitative data (3rd ed.). Sage Publishing.

Shepard, L. A. (1989). "Why we need better assessment?” Educational Leadership, 46(7), 4.

Shepard, L. A. (2000). The role of assessment in a learning culture. Educational Researcher, 29(7), 4-14.

Stark, J. F. (1998). Measurement and evaluation in education. Great \& Great Publishers.

Tekin, H. (2012). Eğitimde ölçme ve değerlendirme (22. baskı). Yarg1 Yayınc1lık.

Tekindal, S. (2009). Okullarda ölçme ve değerlendirme yöntemleri. Nobel Yayıncılık.

Tuncel, G. (2011). Sosyal bilgiler dersinde rubriklerin etkili kullanımı. Marmara Coğrafya Dergisi, 23, 213-233. https://doi.org/10.14781/mcd.291156

Turgut, M. F. ve Baykul, Y. (2012). Eğitimde ölçme ve değerlendirme (4. bask1). Pegem Yayıncılık. https://doi.org/10.14527/9786053640875

Vaughn, P. M. (2002). Enhancing student development in service-learning with performance-based assessment rubrics. Doctoral Dissertation, Arizona State University, U.S.A.

Wengraf, T. (2001). Qualitative research interviewing: Biographic narrative and semi structured methods. Sage Publishing. https://doi.org/10.1002/hrdq.1054

Yıldırım, A. ve Şimşek, H. (2006). Sosyal bilimlerde nitel araştırma yöntemleri (6. baskı). Seçkin Yayıncilik.

Yıldırım, A. ve Şimşek, H. (2011). Sosyal bilimlerde nitel araştırma yöntemleri (8. bask1). Seçkin Yayıncilik. 